\title{
WORLD RED CROSS DAY
}

On 24 April, the League of Red Cross Societies celebrates the fiftieth anniversary of its founding. Its creation was proposed in Cannes in April 1919 at a conference at which medical personalities and Red Cross leaders were assembled. A number of events to which we will subsequently return mark this important anniversary in Geneva.

This date being very close to that of 8 May, traditionally reserved for World Red Cross, Red Crescent and Red Lion and Sun Day, it has been considered opportune for the latter's theme to take its inspiration from the event constituting, for the Red Cross world, the jubilee of the League and that it should at the same time be an affirmation of future prospects. It was in this context that the theme: In a changing world, Red Cross stands for tomorrow was chosen. In addition, many National Societies have decided to celebrate on 8 May the anniversary of the League whose Chairman of the Board of Governors, Mr. José Barroso sends out the following message on the occasion of World Red Cross Day, 1969:

The League of Red Cross Societies is 50 years of age. During half a century, the men, women and young people throughout the world who make up the Red Cross movement have found through their League a place to work together to fight against suffering and for peace within a worldwide federation which today numbers 111 member Red Cross, Red Crescent and Red Lion and Sun Societies.

Working together in the League means many things: it means international solidarity for natural disaster victims and sufferers from sickness, hunger and the even more terrible calamities caused by man himself-war and civil strife. It means discussing and planning together in international conferences, meetings, seminars and study centres-meeting together in assemblies where all barriers of race, religion, politics and ideology are down. It means learning together ways to better health and happiness-and serving together voluntarily wherever there is need.

At its last Executive Committee meeting late in 1968, the League resolved that 1969 would be its 50 th anniversary year and that World 


\section{IN THE Red Cross World}

Red Cross Day, traditionally 8 May, could also be devoted to this event. By reserving a whole year for this commemoration, we felt that every one of the 214 million Red Cross members throughout the world should be able to participate, each in his own way and at a time best suited to his customs, climate, and latitude. The 50th anniversary of the League is not an isolated event, any more than was its foundation in 1919, when many men and women, working over a period of weeks and months, brought to fruition the idea which had germinated in the first post-World War-One European spring. The idea was that the Red Cross, so effective in war, had a role to play in time of peace, if only the forces of many individual National Societies could be brought together.

On May 5 1919, the Articles of Association of the League were signed in Paris. During the ensuing five decades, the world federation has grown from the original five founding Societies, those of France, Great Britain, Italy, Japan and the United States of America, to today's 111. At no time has the growth been more spectacular than in the past few years, and now we approach the goal of true universality.

The peace-time challenges of 50 years ago: suffering caused by natural disaster, disease, hunger, handicaps, and old age are as much as ever with us today and unhappily will continue. That is why we say in our theme for this 50th anniversary year "in a changing world, Red Cross stands for tomorrow". Through its work in developing and encouraging new Red Cross programmes and techniques, in fostering the formation and growth of new National Societies and the training of volunteers, the League is faithful to the wishes of its founders.

Organisations, fortunately, don't age like people. Instead of settling comfortably into late middle age our federation is in fact going through one of the most exciting periods of its life. Instead of commemorating the respectable achievement of half a century of existence we shall be celebrating our arrival on the threshold of an eventful future.

We have been rejuvenated by scientific discoveries and social progress: as these have changed the face of health services they have automatically forced the Red Cross to renew its programmes or adjust its priorities if it is to survive. The explosion of problems which have sprung up with the development of the third world and with which we are still grappling leaves little opportunity to grow old and set in our ways. 